\title{
Palimpsest tunnel valleys: evidence for relative timing of advances in an interlobate area of the Laurentide ice sheet
}

\author{
Alan E. Kehew, Linda P. Nigks, W. Thomas Straw \\ Department of Geology, Western Michigan University, Kalamazoo, MI 49008, U.S.A.
}

\begin{abstract}
During retreat from the late Wisconsinan maximum advance in the Great Lakes region of North America, the Laurentide ice sheet margin became distinctly lobate. The Lake Michigan, Saginaw, and Huron-Erie lobes converged in southern Michigan and Indiana, U.S.A. to form a complex interlobate region. Some time after the glacial maximum, the Lake Michigan lobe advanced over landscapes previously formed by the Saginaw lobe. This can be explained by an asynchronous advance of the Lake Michigan lobe during a Saginaw lobe retreat or by an increase in size of the Lake Michigan lobe relative to the Saginaw lobe during a synchronous readvance.

Cross-cutting relationships in southwestern Michigan, including palimpsest tunnel valleys, document the overriding of Saginaw lobe terrain. Deep, generally straight trenches parallel to glacial flow lines with hummocky, irregular sides and bottoms are interpreted as tunnel valleys. Saginaw lobe tunnel valleys trend northeast-southwest and Lake Michigan lobe tunnel valleys generally trend east-west.

At some time after a Saginaw lobe retreat in southern Michigan, the drumlinized landscape was overridden by an advance of the Lake Michigan lobe to an ice-marginal position at the Tekonsha moraine. Saginaw lobe tunnel valleys in the overridden area were completely filled with ice and debris from the Saginaw lobe retreat at the time of the Lake Michigan lobe advance. Supraglacial and proglacial sediments were deposited over the buried valleys by the Lake Michigan lobe, sometimes by meltwater streams that flowed at high angles to the trends of the valleys. After entrenchment of the Kalamazoo River valley, probably by a subglacial outburst flood, short tributaries were cut nearly at right angles across and through the debris and ice within several buried Saginaw lobe tunnel valleys. After the retreat of the Lake Michigan lobe, subsequent melting of ice in the palimpsest tunnel valleys exhumed the valleys, creating the cross-cutting relationships with the Lake Michigan lobe deposits.
\end{abstract}

\section{INTRODUCTION}

When the late Wisconsinan Laurentide ice sheet reached its southernmost extent at about 21-20 kyr BP, the ice front was oriented roughly east-west through central Ohio, Indiana, and eastern Illinois, with only minor lobate modification (Fig. 1). Ice flowed southward along the axes of the Lake Michigan and Lake Huron basins. Flow lines diverged south of these basins and ice flowing southwesterly out of the Lake Huron basin and southeasterly out of the Lake Michigan basin met along a line in southern Michigan and Indiana.

As the ice retreated, presumably accompanied by thinning of the ice sheet, subsequent readvances were more lobate in character because of topographic control exerted on the thinner ice by the overdeepened troughs of Lake Michigan, Lake Huron, and Lake Erie (Fig. 1). Geomorphic evidence indicates that both the Lake Michigan and HuronErie lobes overrode the area that had previously been occupied by the Saginaw lobe. The large re-entrant along the ice margin in southwestern Michigan (Fig. 1) at approximately $15 \mathrm{kyr}$ BP was formed by: advances of the Lake Michigan and Huron-Erie lobes during retreat of the Saginaw lobe; or during a synchronous readvance of all three lobes, when the advances of the Lake Michigan and Huron-Erie lobes were much stronger and extensive relative to the Saginaw lobe than they had been during previous readvances. Evidence the Lake Michigan lobe advanced over terrain recently occupied by the Saginaw lobe includes tunnel valleys,

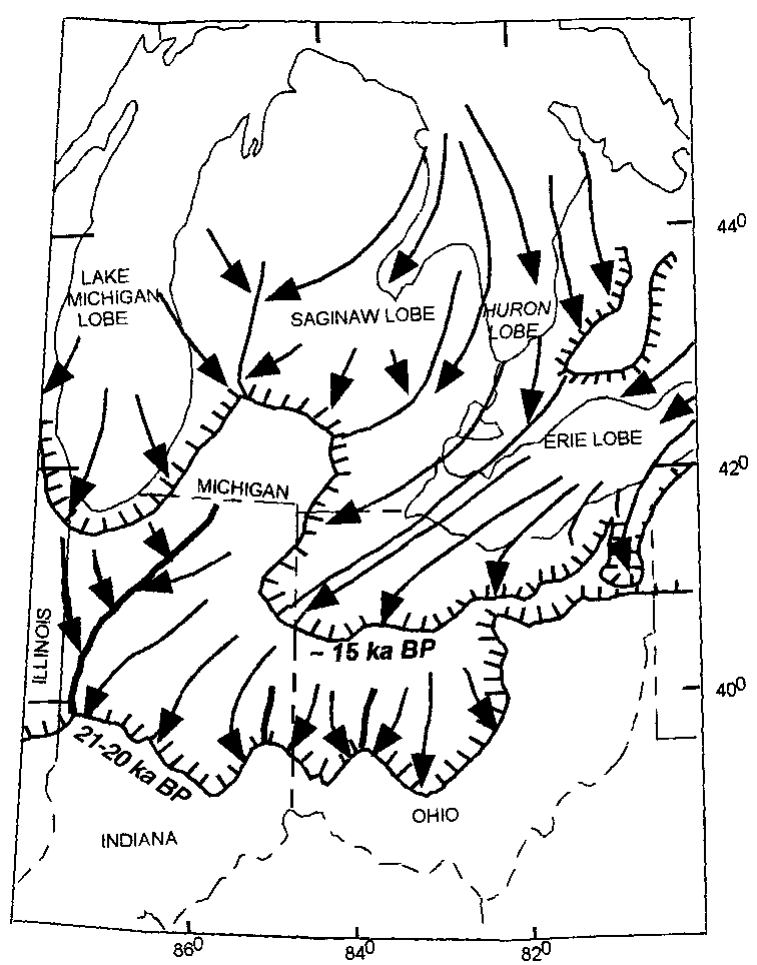

Fig. 1. Ice-marginal positions and approximate flow lines in central Great Lakes region at late Wisconsinan maximum, 21-20 kyr BPand when the ice margin was more lobate, about 15 kyr BP. Modified from Fullerton (1986). 


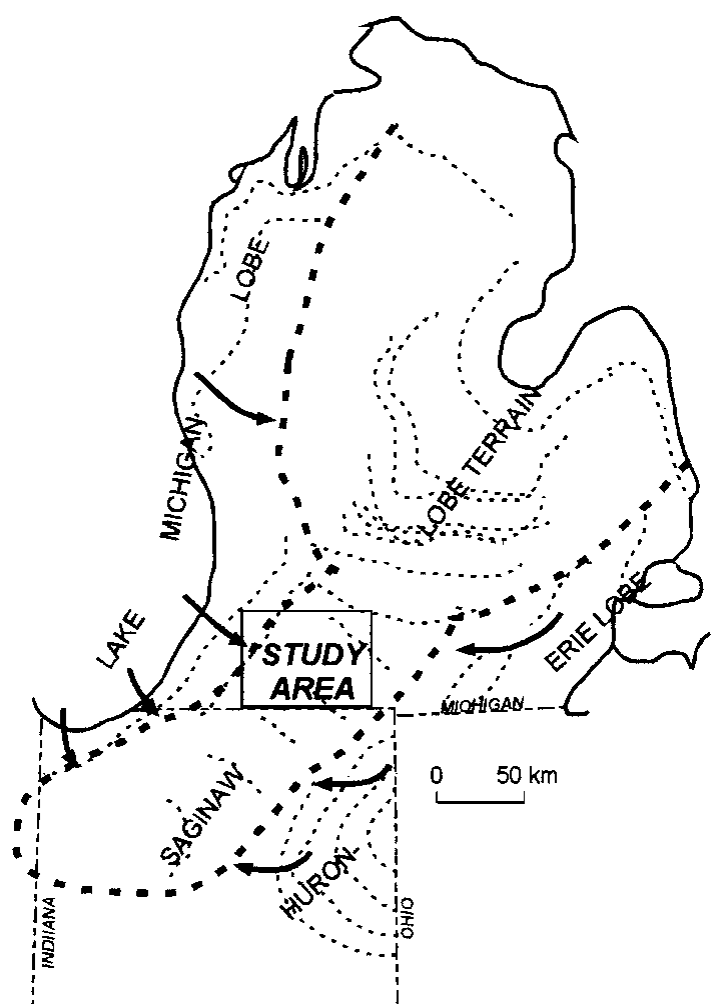

Fig. 2. Study area showing morainal ridges (light dashed lines) formed by Lake Michigan, Saginaw and HuronErie lobes in Michigan and Indiana. The narrow extension of Saginaw lobe terrain to the southwest suggests the Lake Michigan lobe and Huron-Erie lobe overrode terrain previously covered by the Saginaw lobe. Arrows show directions of advance of the Lake Michigan and Huron-Erie lobes.

eroded and filled with stagnant ice and debris during the previous advance and retreat of the Saginaw lobe, that were still filled with stagnant ice when the Lake Michigan lobe overrode them. Later, after sediment was deposited directly by or in front of the Lake Michigan lobe over the filled tunnel valleys, and new valleys were cut at high angles to the buried valleys, the buried ice in the tunnel valleys melted and the overlying debris collapsed to exhume the valleys in the postglacial landscape.

\section{THE SAGINAW LOBE}

The Saginaw lobe, a sub-lobe of the Huron-Erie lobe, established itself as a distinct entity sometime after the late Wisconsinan maximum. The surficial extent of drift deposited by the Saginaw lobe in Michigan (Fig. 2) is defined by a series of moraines concentric to the present outline of Saginaw Bay, most of which were originally mapped by Leverett and Taylor (1915). In southern Michigan and northern Indiana, Saginaw lobe moraines and deposits are confined to a narrow southwest trending zone generally less than $75 \mathrm{~km}$ in width that is truncated by deposits of the Lake Michigan lobe to the west and the Huron-Erie lobe to the east (Fig. 2). If the moraines in this narrow zone are projected parallel to the concentric Saginaw lobe moraines to the north, it is clear the Saginaw lobe occupied a much larger area at some time prior to the advances of the Lake Michigan and Huron-Erie lobes.

Ongoing mapping, in the northern half of the United States Geological Survey Elkhart 1:100 000 quadrangle and the Kalamazoo 1:100 000 quadrangle to the north, supports the hypothesis that Saginaw lobe terrain was overridden by the Lake Michigan lobe and the Huron-Erie lobe, as previously suggested by Zumberge (1960). Before these advances occurred, at the time of the maximum extent of the Saginaw lobe, the Lake Michigan and Huron-Erie lobes were smaller and confined largely to their respective lake basins. The timing of the maximum advance of the Saginaw lobe, and the subsequent overriding by the Lake Michigan and HuronErie lobes, is not well constrained, but is bracketed by the late Wisconsinan maximum and the Cary advance of the Lake Michigan lobe at about 14 kyr BP, during which the lateral margin of the glacier was well west of the study area near the current shoreline of Lake Michigan (Hansel and others, 1985).

\section{LANDFORM-SEDIMENT ASSEMBLAGES IN THE STUDY AREA}

\section{Eastern area-Saginaw lobe terrain}

The study area (Fig. 3) can be divided into an eastern upland characterized by Saginaw lobe subglacial and ice-marginal landform-sediment assemblages, a western area in which Lake Michigan lobe supraglacial landform-sediment assemblages overlie deposits of Saginaw lobe origin, and a central lowland underlain by fluvial and lacustrine proglacial deposits of both lobes. The Saginaw lobe terrain in the eastern part of the study area includes a major recessional moraine, the Sturgis moraine (Figs 3 and 4). The Sturgis moraine is a southeast-trending ridge, about $40 \mathrm{~km}$ long and $10 \mathrm{~km}$ wide, with a high-relief hummocky surface and several ice-walled lake plains. The distal margin of the moraine is characterized by supraglacial and proglacial fan complexes that slope southward into an intermorainal tract extending into Indiana, where they abut older Saginaw lobe moraines. The Sturgis moraine is dissected by several deep, southwest-trending trenches that contain chains of lakes located in depressions along the trench floors (Fig. 4). These valleys are interpreted as tunnel valleys, formed by subglacial meltwater erosion. Several tunnel valleys extend beyond the distal margin of the Sturgis moraine, at least as far southeastward as the next Saginaw lobe moraine, indicating that they were active before the time the ice margin was at the Sturgis moraine. The topography of the bedrock surface beneath the moraine and its distal fans indicates the valleys were eroded into the Mississippian Coldwater Shale bedrock.

From the Sturgis moraine northeastward, the landscape gradually changes from a supraglacial landform assemblage to a subglacial landform-sediment assemblage characterized by drumlins, composed of sandy diamicton and glaciofluvial sediment. This drumlinized till plain, named the Union streamlined plain by Dodson (1985), extends northeastward to a weakly developed Saginaw lobe recessional moraine, the Tekonsha moraine (Fig. 3). A deeply incised trench, $2 \mathrm{~km}$ wide and $50 \mathrm{~m}$ deep, occupied by the Kalamazoo River, lies between the Tekonsha moraine and the next moraine of the Saginaw lobe to the north (Fig. 3).

The Union streamlined plain, along with the stagnation topography and tunnel valleys at the Sturgis moraine, suggest a basal thermal regime similar to the Green Bay lobe west of the Lake Michigan basin, where thawed bed conditions in the ablation area terminated at a frozen marginal 


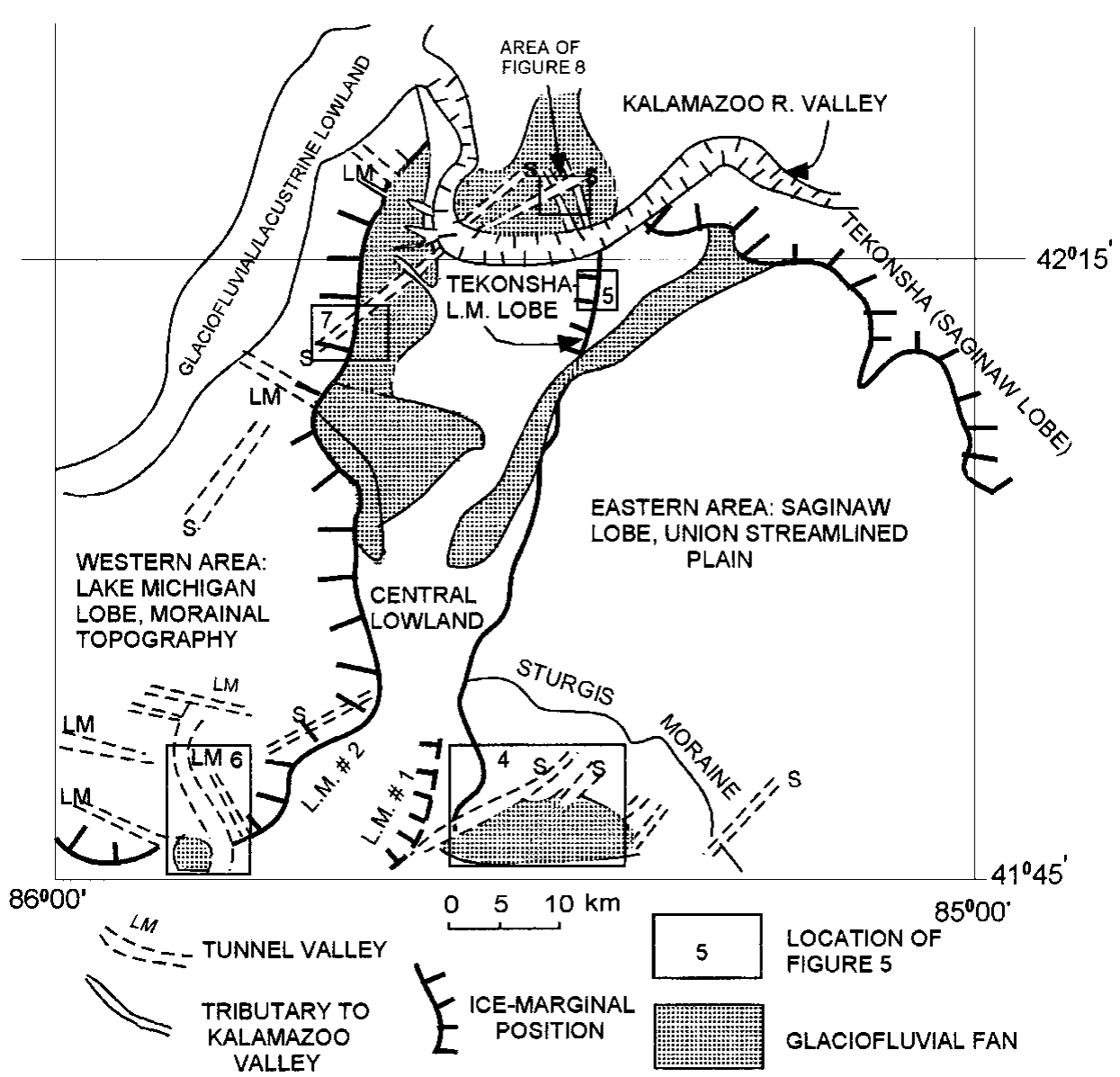

Fig. 3. Ice-marginal positions and distribution of landforms discussed in text, including tunnel valleys associated with Lake Michigan (LM) and Saginaw (S) lobes. Saginaw lobe tunnel valleys west of Lake Michigan ice margin \#1 (L.M. \#1) are palimpsest valleys that were filled with ice and debris during Lake Michigan lobe advance.

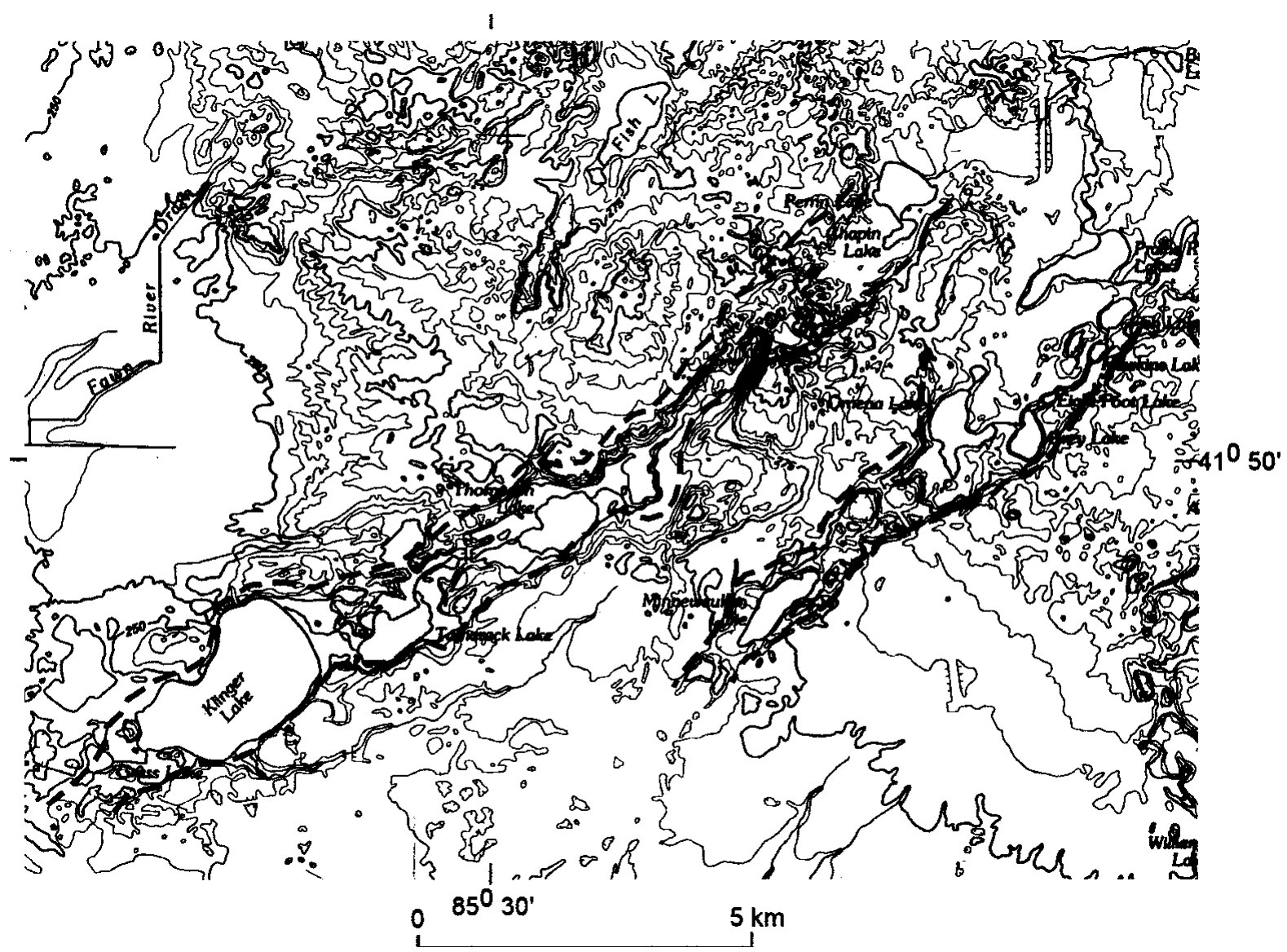

Fig. 4. Part of U.S. Geological Survey 1:100 000 Elkhart quadrangle showing the Sturgis moraine of the Saginaw lobe with two tunnel valleys (dashed lines) that extend beyond the ice margin into the area of proglacial fans. These valleys may have been formed by the Saginaw lobe before its ice margin was at the Sturgis moraine. Contour interval is $5 \mathrm{~m}$. North at top. 


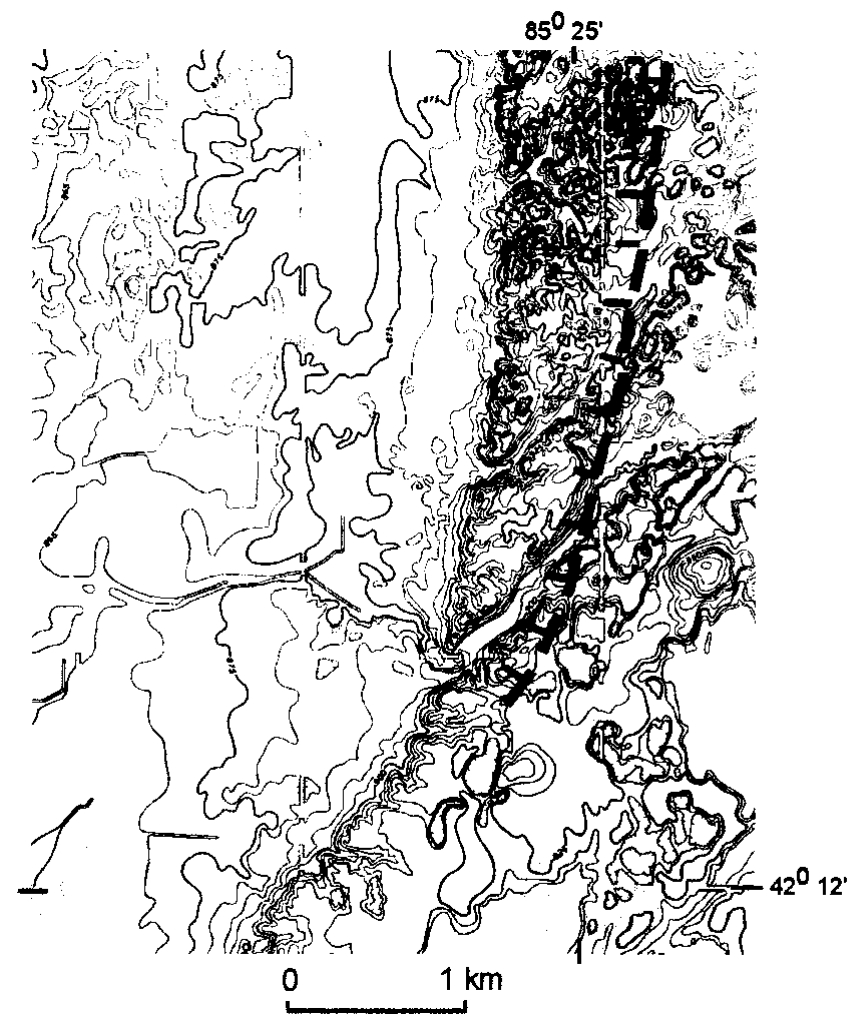

Fig. 5. Part of U.S. Geological Survey Adams Park 1:24000 quadrangle. Hatched line is Lake Michigan lobe, Tekonsha icemarginal position. Topographic scarp west of line is probably wave-cut scarp. Contour interval is $5 \mathrm{ft}(\sim 1.5 \mathrm{~m})$. North at top.

zone (Attig and others, 1989). A frozen marginal zone is suggested by the presence of permafrost until $13 \mathrm{kyr}$ BP (Attig and others, 1989), which would include the time when the Saginaw lobe retreated through the study area. Wet-based conditions behind the margin are consistent with the production of large amounts of meltwater, both from subglacial and supraglacial sources, that could drain subglacially toward the margin and erode deep valleys into the underlying glacial drift and poorly lithified bedrock.

\section{Central interlobate lowland}

In the northern part of the study area, the westward boundary of Saginaw lobe terrain is marked by a steep northsouth trending escarpment (Fig. 5), bounded in places on the west by a thin band of hummocky terrain that Leverett and Taylor (1915) named the Tekonsha moraine of the Lake Michigan lobe. The escarpment was steepened by shoreline erosion from a lake that probably formed as the Lake Michigan lobe retreated to the west (Leverett and Taylor, 1915; Martin, 1957). Dodson (1985) reinterpreted the Tekonsha moraine of the Lake Michigan lobe as a Lake Michigan ice margin buried by outwash from the ice at the Saginaw lobe Tekonsha margin (Fig. 2). In any event, it is clear that the drumlinized Saginaw lobe terrain was truncated by the advance of the Lake Michigan lobe from the west and therefore predates the advance. These cross-cutting relationships indicate the Saginaw lobe was retreating from its maximum extent at the same time that the Lake Michigan lobe was advancing, or that the readvance of the Lake Michigan lobe was much more extensive than the Saginaw lobe.

South of this sharp boundary in the central lowland, a definitive ice-marginal position of the Lake Michigan lobe

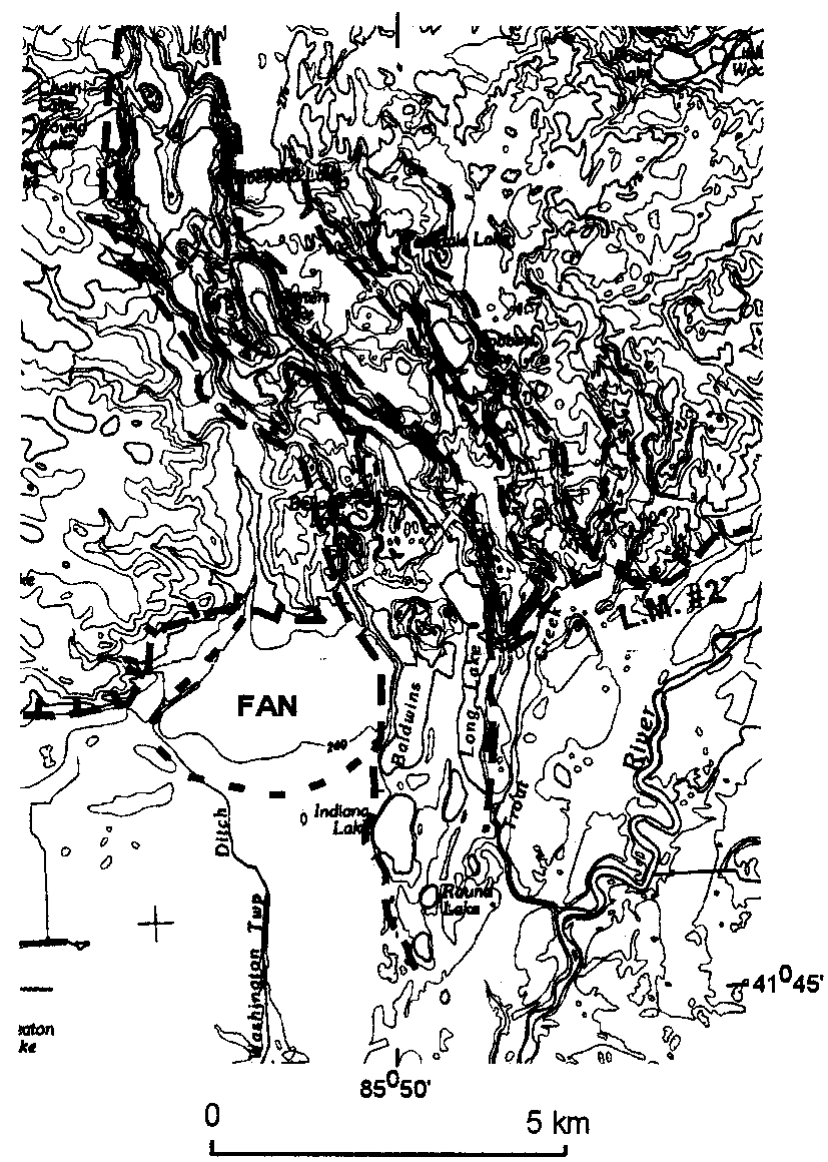

Fig. 6. Part of U.S. Geological Survey Elkhart 1:100 000 quadrangle. Two Lake Michigan lobe tunnel valleys, shown with dashed lines, extend south of Lake Michigan ice margin \#2, indicating the Lake Michigan lobe previously advanced to the southeast. Outwash fan west of tunnel valleys is associated with ice margin \#2. Tunnel valley must have been buried at time of fan deposition. Contour interval is $5 \mathrm{~m}$. North at top.

advance is difficult to place. The lowland is filled with glaciofluvial and glaciolacustrine sediments, including several very large fans originating from both lobes (Fig. 3). The position of ice margin \#1 (Fig. 3) is suggested by the extension of a south-trending Lake Michigan lobe tunnel valley beyond a prominent Lake Michigan lobe ice-marginal position (Fig. 6), and an area of north-trending hummocky topography abutting against the Saginaw lobe terrain on the eastern side of the central lowland (Fig. 3). Lake Michigan ice margin \#1, in the southern part of the study area, is tentatively correlated with the Tekonsha margin of the Lake Michigan lobe in the northern part of the study area (Fig. 3).

\section{Western area-Lake Michigan lobe terrain}

The western part of the study area is occupied by terrain of the Lake Michigan lobe. Lake Michigan lobe ice margin \#2 is mapped at the eastern edge of a large tract of hummocky topography on the western side of the central lowland (Figs 3 and 6). This margin is marked by the edge of the hummocky topography and by the apex of a proglacial outwash fan adjacent to the southeast-trending tunnel valley shown on Figure 6. The tunnel valley must have been filled with buried ice at the time of fan deposition or else fan sediment would have filled the tunnel valley. Zumberge (1960) correlated Lake Michigan lobe margin \#2 of this 


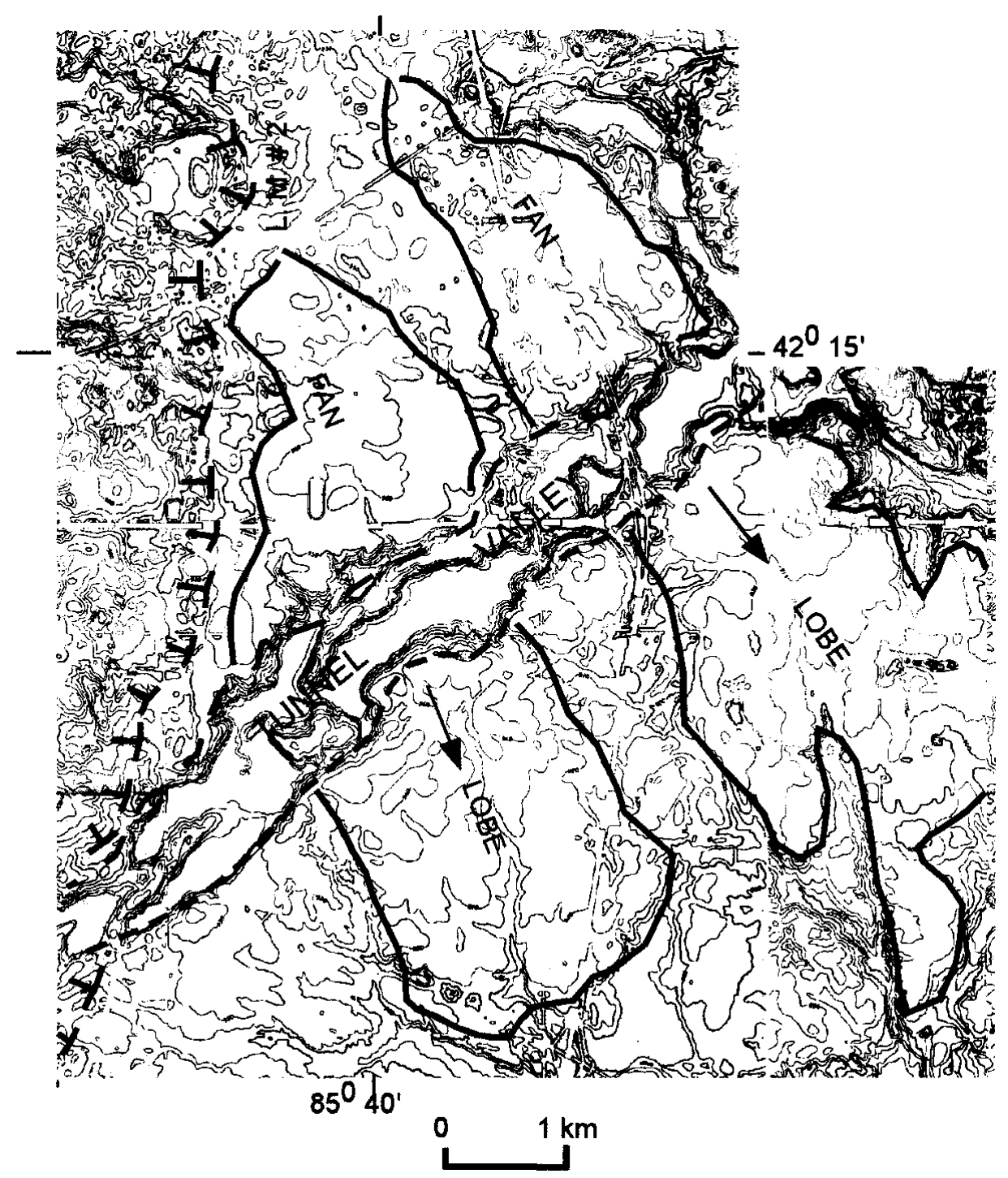

Fig. 7. Part of U.S. Geological Survey Schoolcraft NW, Kalamazoo and Portage 1: 24000 quadrangles. Palimpsest Saginaw lobe tunnel valley extends beyond Lake Michigan ice margin \#2 from southwest to northeast. Outwash fan lobes slope continuously across valley, indicating that tunnel valley was filled with ice and debris at the time of fan deposition. Contour interval is $10 \mathrm{ft}$ $(\sim 3 m)$. North at top.

paper to the Lake Michigan lobe Tekonsha moraine to the north, a correlation that is possible, but is rejected in favor of the position of the northern extent of margin \#2 shown on Figure 3, which connects the apices of several large fans that originate at the margin.

West of Lake Michigan lobe margin \#2, several straight, southwest-trending, highly collapsed valley segments are interpreted as Saginaw lobe tunnel valleys overridden by the Lake Michigan lobe (Figs 3 and 7). Preservation of these valleys suggests they still contained buried ice as the Lake Michigan lobe advanced over them, which later melted to create the existing topography of the valleys. The tunnel valley shown in Figure 7 extends northeast of Lake Michigan ice margin \#2. Slopes on outwash fan lobes (Fig. 7), derived from Lake Michigan ice margin \#2, grade smoothly across the tunnel valley indicating the valley was filled with buried ice at the time ice stood at the margin and the fan lobes were deposited.

The Lake Michigan lobe terrain also contains hummocky, irregular linear depressions trending east-west (Fig. 3), which is the expected orientation for tunnel valleys produced by the Lake Michigan lobe in this area. A major valley of this type in the central part of the study area terminates at Lake Michigan ice margin \#2, at the apex of several large fans that cover much of the central lowland to the east.

The broad, deeply entrenched Kalamazoo Valley cuts across the northern part of the study area (Fig. 3). The size and form of this valley correspond to valleys produced by catastrophic outburst floods along the southwestern margin of the Laurentide ice sheet in North Dakota, Saskatchewan, and Manitoba (Kehew and Teller, 1994). Meltwater that eroded the Kalamazoo River valley apparently originated from the Saginaw lobe, perhaps from a subglacial outburst when the lobe stood at a moraine north of the study area. This water flowed westward across the central lowland of the study area and into the Lake Michigan lobe terrain to the west, sometime after the retreat of the Lake Michigan lobe from ice margin \#2. After the Kalamazoo Valley was rapidly entrenched, short tributary valleys leading to the trench were incised, probably by normal surficial runoff rather than glacial meltwater (Figs 3 and 8). These valleys cross southwest-trending Saginaw lobe tunnel valleys at right angles in several locations (Fig. 8). The establishment 


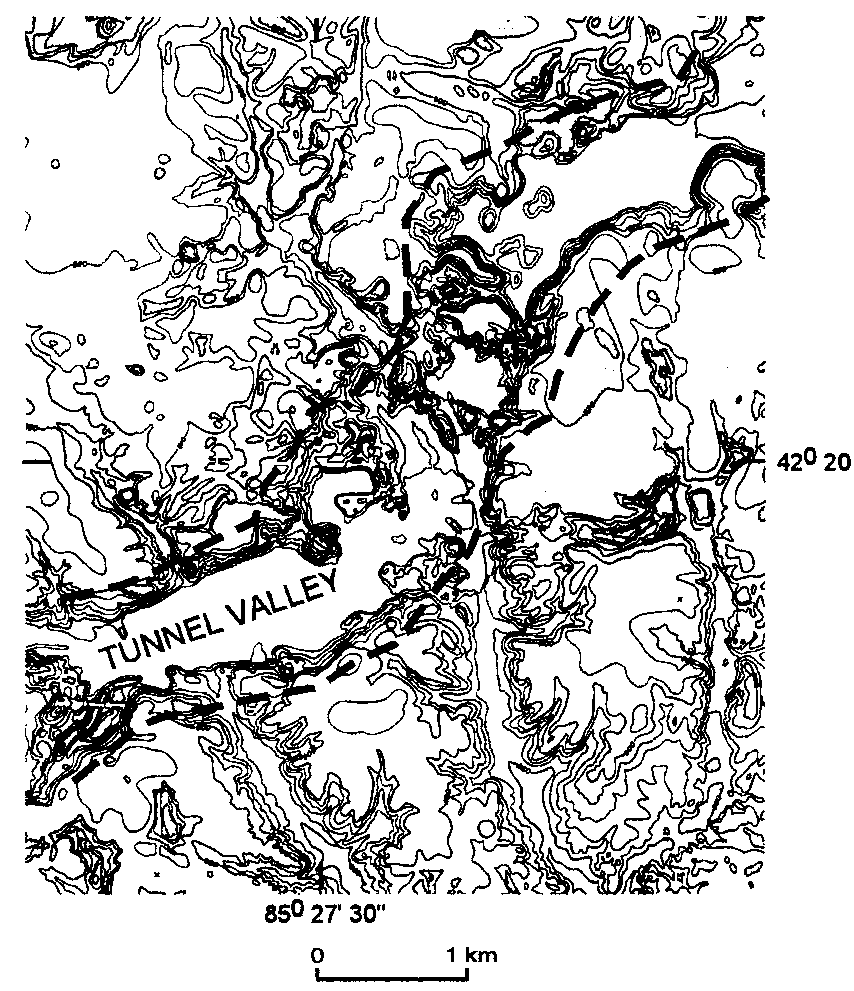

Fig. 8. Part of U.S. Geological Survey 1:24000 Galesburg quadrangle. Palimpsest Saginaw lobe tunnel valley shown with dashed line. South-trending valleys were cut across buried tunnel valley as tributaries to the Kalamazoo River valley, south of map. Contour interval is $10 \mathrm{ft}(\sim 3 \mathrm{~m})$ North at top.

of these drainage ways across the older tunnel valleys would have been impossible unless the tunnel valleys were still filled with ice and debris. Later, following melting and collapse of the buried ice in the tunnel valleys, the anomalous occurrence of valleys crossing at right angles was produced.

\section{FORMATION OF TUNNEL VALLEYS}

Evidence indicates that the Saginaw and Lake Michigan lobes were primarily wet-based at the time of the formation of the landform-sediment assemblages within the study area. These include: the large drumlinized Union streamlined plain (Dodson, 1985); and the abundance of glaciofluvial and glaciolacustrine sediment within moraines, as well as proglacial areas. If, as postulated for the Green Bay lobe in Wisconsin, the lobe margin was frozen to its bed, basal meltwater flowing toward the margin would be impounded against the proximal side of the frozen margin. The eventual breakthrough of meltwater probably occurred, perhaps as discrete events, by the erosion of a subglacial trench into the underlying glacial drift and the weak Coldwater Shale bedrock. Portions of these valleys could be reoccupied by subglacial drainage during subsequent advances or readvances, thus explaining why the valleys extend beyond some ice-marginal positions. Some of the tunnel valleys could also be related to an episodic surge behavior, with large releases of subglacial water just prior to the termination of a surge and subsequent marginal stagnation, in a manner similar to that suggested by Patterson (1997) for the Des Moines lobe. Debris-covered ice then collapsed filling the trenches during retreat to the level of the adjacent land surface. The buried ice was probably insulated with debris and therefore melted very slowly, so when the ice readvanced over the area, sediment was deposited and cross-cut valleys were incised without any control by the buried tunnel valleys.

Within the study area, the proposed tunnel valleys lie in only two orientations, each parallel to the flow lines and perpendicular to the ice margins of either the Saginaw or Lake Michigan lobes. These trends, along with the linearity of the valleys, strongly suggest an ice-directed, basal origin for the valleys rather than other origins, such as erosion by proglacial streams.

\section{CONGLUSIONS}

The sequence of events proposed for the study area includes a relatively rapid retreat of the Saginaw lobe accompanied by advances of the Lake Michigan lobe into the recently deglaciated area, or an overall retreat followed by a much stronger readvance of the Lake Michigan lobe relative to the Saginaw lobe. Palimpsest tunnel valleys provide the best geomorphic evidence for these relationships. At the time of the advance of the Lake Michigan lobe, there was no topographic expression of debris-filled Saginaw lobe tunnel valleys. Supraglacial sediments and proglacial fans were deposited over the buried tunnel valleys. Later, after incision of the Kalamazoo outburst channel, tributary valleys were cut across the fan sediment overlying the buried tunnel valleys. Not until all of these events had taken place did the buried ice melt to produce the highly collapsed and hummocky valleys of the present landscape.

\section{REFERENGES}

Attig, J.W., D. M. Mickelson and L. Clayton. 1989. Late Wisconsin landform distribution and glacier-bed conditions in Wisconsin. Sediment. Geol., 62(3-4), 399-405.

Dodson, R. L. 1985. Topographic and sedimentary characteristics of the Union streamlined plain and surrounding morainic areas. (Ph.D. thesis, Michigan State University.)

Fullerton, D. S. 1986. Stratigraphy and correlation of glacial deposits from Indiana to New York and New Jersey. Quat. Sci. Rev., 5, 23-37.

Hansel, A. K., D. M. Mickelson, A. F. Schneider and C. E. Larsen. 1985. Late Wisconsinan and Holocene history of the Lake Michigan basin. In Karrow, P. F. and P. E. Calkin, eds. Quaternary Evolution of the Great Lakes. St. John's, Nfld, Geological Association of Canada. Memorial University of Newfoundland, 39-53. (GAC Special Paper 30.)

Kehew, A. E. and J. T. Teller. 1994. History of Late Glacial runoff along the southwestern margin of the Laurentide ice sheet. Quat. Sci. Rev., 13(9-10), 859-877.

Leverett, F. and F. B. Taylor. 1915. The Pleistocene of Indiana and the history of the Great Lakes. U.S. Geol. Surv. Monogr. 53.

Martin, H. M. 1957. Outline of the geologic history of Kalamazoo County. Lansing, MI, Michigan Department of Natural Resources. Geological Survey Division.

Patterson, C. J. 1997. Southern Laurentide ice lobes were created by ice streams: Des Moines lobe in Minnesota, U.S.A. Sediment. Geol., 111(1-4), 249-261.

Zumberge, J. H. 1960. Correlation of Wisconsin drifts in Illinois, Indiana, Michigan, and Ohio. Geol. Soc. Am. Bull., 71, 1177-1188. 